International Journal of Social Sciences and Humanities
Available online at http://sciencescholar.us/journal/index.php/ijssh
Vol.1 No. 3, December 2017, pages: 97 107
e-ISSN: 2550-7001, p-ISSN: 2550-701X
http://dx.doi.org/10.21744/ijssh.v1i3.60

\title{
Community Based Tourism Development
}

I Made Suniastha Amerta a
Article history: Received 12 July $\begin{aligned} & \text { Crossark } \\ & \text { Accepted in revised form } 20 \text { November 2017, Approved } 29 \text { November } 2017 \\ & \text { Available online } 15 \text { December } 2017\end{aligned}$
Correspondence Author a

e-ISSN : 2550-7001, p-ISSN : 2550-701X(C) Copyright 2017. The Author. SS Journals Published by Universidad Técnica de Manabí.

This is an open-access article under the CC BY-SA 4.0 license (https://creativecommons.org/licenses/by-sa/4.0/) All rights reserved.

\section{Contents}

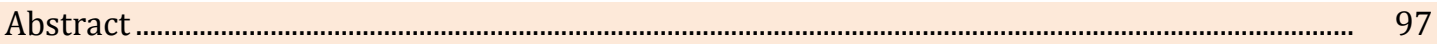

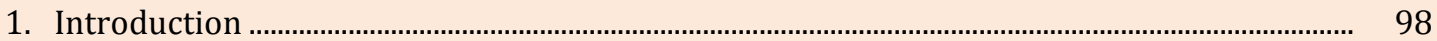

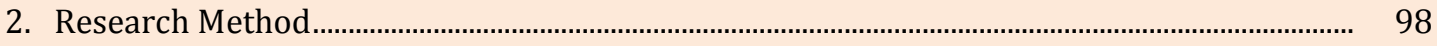

The Concept of Tourism Development............................................................................................. 98

a Faculty of Economics, Warmadewa University, Denpasar-Indonesia 


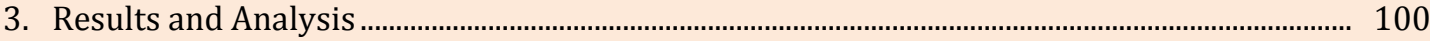

The Tourism Development Strategy Model .................................................................................... 100

The Community-Based Tourism Development in Karangasem ................................................. 101

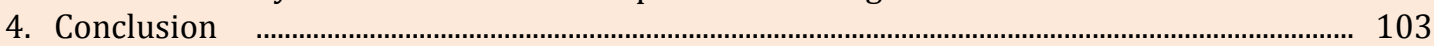

Acknowledgements [................................................................................................................... 104

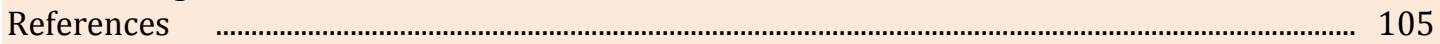

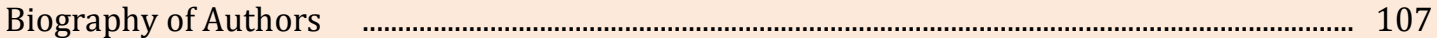

\section{Introduction}

Karangasem is one of nine regencies/municipalities in Bali Province and geographically is located in the eastern tip of Bali. The Regency has a variety of tourism potential, particularly for the cultural tourism and nature tourism development which should continue to be extracted and developed as a capital of tourism development in this regency in the future time.

In accordance with the Bali Provincial Regulation Number 16, 2009 on the regional spatial plan of Bali Province 2009-2029 replacing the Bali Provincial Regulation Number 4, 2005 has set three tourism area located in Karangasem Regency of totally sixteen tourism area in Bali province. Those three tourism zones namely Candidasa tourism zone, Tulamben tourism zone, and Ujung tourism zone as presented in the following table.

The Tourism Zone in Karangasem Regency

\begin{tabular}{|c|c|c|c|}
\hline No & Name of Tourism Zone & Location (Village) & (District) \\
\hline 1 & Candidasa Tourism Zone & $\begin{array}{l}\text { Bugbug Village, Pertima Village, } \\
\text { and Subagan Village } \\
\text { Antiga Kelod Village, Antiga } \\
\text { Village, Padangbai Village, Ulakan } \\
\text { Village, Sengkidu Village, and Nyuh } \\
\text { Tebel Village }\end{array}$ & $\begin{array}{l}\text { District of } \\
\text { Karangasem } \\
\text { District of Manggis }\end{array}$ \\
\hline 2 & Tulamben Tourism Zone & $\begin{array}{l}\text { Baturinggit Village, Kubu Village, } \\
\text { Dukuh Village, and Tulamben } \\
\text { Village } \\
\text { Datah Village, Purwakerthi } \\
\text { Village, and Bunutan Village }\end{array}$ & $\begin{array}{l}\text { Kubu District } \\
\text { Abang District }\end{array}$ \\
\hline 3 & Ujung Tourism Zone & $\begin{array}{l}\text { Karangasem Village, Tumbu } \\
\text { Village, Seraya Barat Village, } \\
\text { Seraya Village, and Seraya Timur } \\
\text { Village }\end{array}$ & Karangasem District \\
\hline
\end{tabular}

(Source: Karangasem Regency Tourism Office, 2013)

Karangasem Regency has focused on developing tourism sector nearly in all part of the Regency. The development of alternative tourism in the form of tourist villages, which substantially its development is always based on community-based tourism development and sustainable development. The development of a tourist village aims to provide opportunities for local people to manage tourism in their villages.

\section{Research Method}

\section{The Concept of Tourism Development}

According to ${ }^{1}$ as cited in ${ }^{15}$, conceptually, development is defined as a process of fundamental change in the society of particular national circumstances into other valuable national circumstances. Related with the tourism sector, the tourism development can be interpreted as a process of change that will be carried by a man in a planned to a certain tourism conditions were 
rated poor, which is directed toward a specific tourism conditions are considered better or more desirable. ${ }^{15}$

Based on the opinion ${ }^{16,17}$, it can be concluded that in the field of tourism, development is considered as a process of development undertaken by the community through a clear plan and direction, to achieve better than before. To achieve the goal of optimally tourism development, tourism experts constantly strive to find and dig to find out the meaning of the goals and strategies to achieve the tourism conditions are considered better and more valuable. ${ }^{18,19}$

Paradigm, intellectuals have understood as a person's perspective on themselves and their environment which will influence the thinking act and behave on a particular phenomenon. ${ }^{20,21}$ On the other meanings limitation, the development paradigm can also mean a set of assumptions, concepts, values, and strategies were implemented to perceive and anticipate a phenomenon reality of a community in the same perspective, especially in a particular discipline. The various notions of development paradigm, however, if it is associated with the development of tourism, the paradigm of tourism development could be defined as a set of assumptions, concepts, values, and practices of the strategy adopted in the development of tourism. On the other words, the paradigm of tourism development, is a framework or a thinking model that used to underline the overall planning of tourism development in a community, in a certain period of time. ${ }^{22}$

An implementation model and development strategy planning in the field of tourism also never escape the monitoring and evaluation of observers and thinkers of tourism development. The results of these observations and thoughts in many ways has spawned criticism of the performance and operation of a model and strategy planning of certain development and eventually led to alternative models and strategies of tourism development planning new ones. ${ }^{23}$ Therefore, the various models and alternative strategies in the planning of tourism development have alternated and emerged as a consequence of criticism and rethinking of the paradigm of tourism development in certain places. ${ }^{24}$

According to Sunaryo, whatever the model and implemented paradigm, at least there are four rules that should be the spirit of impartiality of a model of development planning and strategy in the field of tourism. The four following rules must always become the underlying model and strategy of tourism development plan.

1. The Siding with the vision, mission, goals, and objectives of a particular priority of the process of tourism development to be held. Overall the document's vision, mission, goals, and objectives are usually formulated by the political will of the parties the competent authority.

2. The adaptive flexibility growth of tourism development in accordance with the dynamics of social development, economy, culture, and politics in the area of national and international

3. Maintaining the sustainability of tourism development which has included the anticipation for the demanding needs for generations to come.

4. Anticipating and responsive in the plan for a tourism development should always pay attention, taking into account, and consider the overall dynamics of the situation and the reality of the reality of tourism in the entire region concerned..$^{15}$

There are six phases of tourism development and theoretically, give different implications and impacts. Those six phases are as follows. ${ }^{4}$

1. Exploration phase (exploration, spontaneous growth and exploratory).

At this stage a relatively small number of adventurous travelers. They tend to be exposed to the natural and cultural beauty unspoiled tourist destination. Tourism facilities and services obtained is also not good travelers. Things to do in the area of travel and tourism has not been changed by contact with the local community is relatively high.

2. Involvement phase (engagement).

At this stage, it begins the local community initiatives to provide tourist facilities, and the promotion of the tourist area started with the help of government involvement. A result is an increasing number of tourists.

Amerta, I. (2017). Community Based Tourism Development. International Journal Of Social Sciences And Humanities (IJSSH), 1(3), 97-107. doi:10.21744/ijssh.v1i3.60 
3. The Phase of development (development and construction).

At this stage, the number of tourist arrivals increased sharply. At the peak tourist season usually equaled, even outnumber the local population. Outside investors flock to renew the facility. In line with the increasing number and popularity of the area of tourism, the problems of the destruction of the facility began. Planning and control of national and regional be needed, not only to solve problems that occur but also for international marketing.

4. The stage of consolidation (consolidation)

At this stage, the growth rate has begun to decline, although the total number of tourists is still relatively increased. Inexperienced tourist areas around the problem and the likelihood of a very strong monopoly.

5. The stagnation phase (stability).

At this stage the number of tourists who come to the peak, tourists are no longer able to be served by a tourist destination. It was realized that replicates the visit of tourists and business utilization and other supporting components are needed to maintain the number of tourists who visit. A tourist destination may encounter environmental issues, social and economic.

6. Phase decline (loss of quality) and Rejuvenation (reborn).

At the stage of decline, the visitors lost tourist destination known to the original and becomes the 'resort' new. 'Resort' to be dependent on geographic catchment areas smaller for the daily trips and weekend visits. Ownership strong opportunity for change and tourism facilities, such as accommodation will change its utilization. Finally, policymaking admits at this stage and decided to be developed as a 'new birth'. Finally, there should new policies in various fields, such as the use, marketing, distribution channels, and reviewing the position of the destinations.

\section{Results and Analysis}

\section{The Tourism Development Strategy Model}

Along with the demands and escalation needs change, a shift in the mindset of the world community, and the dynamic development of the strategic issues that will affect the tourism development it has finally grown at least three variants of the model planning strategy of tourism development which is often used as a reference base by the tourism development planners. The tourism development planning strategies are as follows.

1. Strategic planning of tourism development that prioritizes growth (growth-oriented model).

2. Strategic planning of tourism development, which is based on empowering the community (community-based tourism development),

3. The tourism development planning strategy rests on the sustainable development of tourism (sustainable tourism development).

The planning of tourism development can be defined as a process of preparing a rational and systematic of all tourism activities that will be undertaken to achieve a specific purpose and a way to achieve the objectives and allocate overall resources optimally. ${ }^{9}$ The planning of tourism development can also be defined as a prediction and projection into the future through a process that describes the desire and needs to be achieved through the entire consideration of the analysis of the situation and experiences in stating the purposes of tourism that will be realized. ${ }^{15}$ Planning is one of the functions of management which has an important role in any development. In this case, a good and an implemented planning, however, can optimize and get easier to realize the goals of tourism development.

In addition, the implementation of the tourism development program will affect the existence of values that most fundamental to personal life, family, community and even for the nation. Therefore, tourism development planning should be done very carefully, deeply, and precisely, and responsive in anticipating the overall conditions that will occur in the future time. 
Sunaryo added, in order to provide the basic spirit and direction of a clear objective nature drafting a strategy for tourism development planning, then there are several principles that need to be kept in mind by tourism planners, they are as follows.

1. Allocative. The planning process should be more emphasis synchronization and coordination in order to attempt to find a solution and compromise of differences and conflicts of interest that arise, both from the stage to the implementation plan. Coordination has an important role in solving the problem. In the event of conflicts in planning, surely there is a difference between the parties involved that need to be solved. This form of planning emphasis on coordination and finding a solution.

2. Innovative, a tourism development planning to the final goal is to achieve the realization of the mission of the tourism conditions which are more valuable, and therefore in the implementation should be able to lead to a better renewal.

3. Single and multi-objective. The principle of tourism development planning is flexible in the sense intended to result in one or several development targets at once. Thus, in the preparation of a tourism development planning can lead to a form of a single project or the plural form of the project (multi projects).

4. Indicative. What is meant by the indicative principle here is that tourism development planning should provide an indication of the program that will provide clues about the direction of policy and program in general or an outline? Based on the indicative program, it is meant to guide to the right action programs or planning activities in a more detailed action programs.

5. Imperative. In this sense means that in designing a tourism development plan, it must be implementable within the meaning must be followed by the existing stakeholders, both from the public sector and industry-related parties..$^{15}$

The principle, a planning document of tourism development should always be directed to develop a tourist attraction with a good tourism governance system. This is done to give positive implications both economically, and social culturally to the tourism stakeholders, such as the local communities, governments, and tourism investors.

\section{The Community-Based Tourism Development in Karangasem}

The Community-based development is a discourse that must be put forward in order to achieve the success of development in various sectors, including the tourism sector. The community-based tourism development discourse which is currently often used as the basis of tourism development either nationally, regionally, or internationally.

The community-based tourism is synonymous with sustainable tourism development and is often associated with alternative tourism. It wants to balance between natural resources, social and community values, thus positively beneficial for local people and tourists. Forms of tourism that are consistent with natural, social, and community values and the which allow both hosts and guests to enjoy the positive and worthwhile interaction and shared experience. ${ }^{5}$ In the development of community-based tourism, local people are considered as the main actors. This is because the local community knows more the potential of the area or the character and ability of the elements that exist in the village, including indigenous knowledge possessed by the people. So, the construction of which is planned as desired by and for the local communities. ${ }^{1}$

The community-based tourism wants to balance between the resources, people, and tourists. These benchmarks based on community-based tourism development is the creation of a harmonious relationship between the local communities, natural resources/culture, and tourists, which can be seen from the followings. ${ }^{15}$

1. There is an increasing enthusiasm for community development through the establishment of an organization to accommodate all the aspirations of the community, through a system of collaboration between government and local communities.

2. The sustainability of the physical environment that exists in society, the way is through conservation, promotion and creating harmonious life goals between natural resources,

Amerta, I. (2017). Community Based Tourism Development. International Journal Of Social Sciences And Humanities (IJSSH), 1(3), 97-107. doi:10.21744/ijssh.v1i3.60 
cultural resources, and human resources. The rediscovery of the potential of natural resources, and cultural resources.

3. The existence of economic sustainability through equity and justice in enjoying the fruits of development.

4. Build a system which benefits society as a system of information that can be used together.

5. Maintain traveler satisfaction through better service, provision of information is effective, efficient, and prioritize convenience for tourists. ${ }^{11}$

To produce sustainable community-based tourism is done by a variety of systems approach and unified whole, is inter-discipline, participatory, and holistic between the related components. The forms of community-based tourism development can be done in three ways, namely, (1) selfhelp (entirely from the public); (2) partnership (through employers lifting); and (3) mentoring by NGOs or community college party during deemed not able to be independent, but if they were deemed capable of self then slowly abandoned by chaperones. ${ }^{2}$

Conceptually, tourism development can not be separated from the power source and the uniqueness of the local community. The elements can be physical and non-physical (traditions and culture), which are an element of the main drivers of tourist activities themselves. So the tourism should be viewed as "activity based on local community". It also stated that a variety of definitions of Community-Based Tourism (CBT) with the characteristics of the following restrictions. ${ }^{15}$

1. The form of governance of tourism which provides the opportunity for local communities to control and actively involved in the management and development of tourism.

2. The form of governance of tourism that can provide opportunities for people who are not directly involved in tourism businesses can also get benefit from existing tourism.

3. This form of tourism that demands a systematic empowerment and democratic and fair distribution of benefits to disadvantaged communities in destinations.

In principle, CBT is closely related to the certainty of the active participation of local communities in tourism development there. Community participation in tourism consists of two perspectives: public participation in decision-making and participation with regard to the distribution of profits earned by the community of tourism development. Therefore, basically, there are three (3) basic principles in the strategy of community-based tourism development planning (CBT); those are mentioned below.

1. Involving community members in decision-making

2. The certainty of the local communities benefit from tourism activities, and

3. Education of tourism for local communities.

Basically, there are 10 basic principles that need to be considered by tourism development planners, which ultimately led to the principle that the more balanced relationship between tourists and local communities in the tourism industry. Balance referred to, among others in terms of the ownership status of assets of community control, equitable benefit sharing, cultural and social relations based on mutual respect, and joint efforts to safeguard the environment. ${ }^{15}$

The ten basic principles referred to in essence that must become the foundation and direction of tourism development which is expected that it will be able to safeguard the sustainability of tourism itself. The ten basic principles earlier are as follows:

1. Recognizing, supporting, and developing community ownership in the tourism industry.

2. Involving community members in starting every aspect of tourism development stage.

3. Develop community pride.

4. Developing the quality of community life.

5. Ensure environmental sustainability of tourism.

6. Maintaining the unique character and culture in tourist destinations

7. Assist the development of learning about cultural exchange in the local community.

8. Respect for cultural diversity and human dignity in the destination environment.

9. Distributing fairly the advantages of tourism in the destination community members. 
10. Take an active role in determining the percentage of revenue from each activity (equitable income distribution) tourism associated with the local community.

The development of community-based tourism has some ideal characteristics as follows: ${ }^{14}$

1. Businesses which developed a small-scale, not a large (giant) scale.

2. Ownership and management performed by the local community (locally owned and managed).

3. In accordance with the small scale and managed by local communities, the majority of the inputs used, both during construction and operation, from the local area so that small import component.

4. Activities chain (Spin-off activity) caused a lot, hence the involvement of the local community, both individually and institutionally, becomes larger.

5. The activities of the chain provide greater direct benefits for local communities.

6. Based local culture, because the victims were local residents.

7. Development of environmentally friendly, associated with the conversion of land on a large scale, and the absence of changing the form of the landscape means.

8. Attachment of local wisdom because people have adapted to the natural surroundings.

9. The distribution is not concentrated in one area but can be spread every related area.

The development of community-based tourism is expected to provide some benefits for society, particularly the economic benefit. So, the environmental preservation can be implemented by the local communities, their population distribution, and creating alternative tourism. The economic benefit received by local communities is to provide goods and services needed by tourists. The provision of goods and services can be done by women while the men work in the fields. The rural tourism creates jobs for women. ${ }^{2}$ This opinion is supported by Schneider, the incentive for local farmers and equity and expanding agricultural production to meet the food needs of the tourists.

In addition, the concept of tourism development which is based on the community should also be considered a concept of balance between resources and resident. In a development that is integrated, which society as key players of tourism activities. Therefore, based on communitybased tourism development in various forms of a tourist attraction, ahead referable alternative tourism development, especially in Karangasem regency.

The beautiful panoramic view of nature, culture, and various potentials, Karangasem regency is well-deserved to be a fascinating tourism destination with activities to do, such as trekking, diving, snorkeling, rafting, and fishing. In addition, there are also various traditional cultures laden with the uniqueness of local customs in every major Hindu religious ceremony such as Usaba Sembah and Mekare-kare with pandanus war in Tenganan Village, Usaba Dangsil in Bungaya Village, Usaba Dodol in Selat Village, Gebug Ende in Seraya Village (Karangasem Tourism Office, 2013). Some of the natural and cultural potentials of the people of Karangasem Regency have been explored and developed as an alternative tourism development, such as spiritual tourism, ecotourism, agrotourism, and tourist villages. So, the community-based tourism development is very suitable applied in the regency of Karangasem.

\section{Conclusion}

Based on the above description, we can conclude the following matters:

1. In the construction and development of tourism in a tourist destination, it needs to do such careful planning, integrated, and holistic to consider various aspects of tourism.

2. The construction and tourism development should have positive implications for tourism stakeholders, i.e. local communities, governments, and investors, in the economic, sociopolitical, cultural, and environmental.

3. One of the strategies which can be adapted in the development of tourism in Karangasem Regency is the community-based tourism development (CBT Development).

Amerta, I. (2017). Community Based Tourism Development. International Journal Of Social Sciences And Humanities (IJSSH), 1(3), 97-107. doi:10.21744/ijssh.v1i3.60 
4. The Government of Karangasem regency as part of the tourism stakeholders responsible for the success or failure of development and tourism development in Karangasem regency.

\section{Acknowledgements}

The author would like to thank and deliver a high appreciation to the Rector of Warmadewa University and the Dean of Faculty of Economics of Warmadewa University. Thanks is also referred to the Head of Management Study Program Warmadewa University for any facility that has been given to the author. 


\section{References}

1. Adhisakti, L. T. (2000). Strategi Pengembangan Desa Wisata Di Indonesia. In Dalam Makalah Seminar Nasional.

View in (Google Scholar)

2. Ardika, I. W. (2007). Pusaka budaya dan pariwisata. Pustaka Larasan.

View in (Google Scholar)

3. Ardika, I. W. (2015). Warisan budaya perspektif masa kini. Udayana University Press.

View in (Google Scholar)

4. Butler, R. W. (1992). Alternative tourism: The thin edge of the wedge. Tourism alternatives, 3146.

View in (Google Scholar) (Scopus)

5. Smith, V. L., \& Eadington, W. R. (Eds.). (1992). Tourism Alternatives: Potentials and problems in the development of tourism. University of Pennsylvania Press.

View in (Google Scholar) (Scopus)

6. Gee, C. Y. And Fayos-Sola, Eduardo. 1999. International Tourism: A Global Perspective. Madrid: WTO.

View in (Google Scholar) (Scopus)

7. Hadinoto, K. (1996). Perencanaan Pengembangan Destinasi Pariwisata. Jakarta: Universitas Indonesia.

View in (Google Scholar)

8. Christie Mill, R. (2000). Tourism, The International Business (Edisi Bahasa Indonesia). PT. Raja Grafindo Persada Jakarta.

View in (Google Scholar)

9. Inskeep, E. (1991). Tourism planning: an integrated and sustainable development approach. Van Nostrand Reinhold. View in (Google Scholar) (Scopus)

10.Nasikun. (1997). "Model Pariwisata Pedesaan: Pemodelan Pariwisata pedesaan untuk Pembangunan Pedesaan yang Berkelanjutan," dalam Myra P Gunawan (ed.),, Perencanaan Pariwisata Berkelanjutan. Prosiding Pelatihan dan Lokakarya. Penerbit : ITB Bandung. View in (Google)

11.Natori, M. (2001). A Guide Book for Tourism Based Community Development. Aptec OsakaJapan.

View in (Google Scholar) (Scopus)

12. Artini, N. W. P., \& Anggreni, I. L. (2006). Peranan Desa Adat Dalam Pengelolaan Kepariwisataan (Studi Kasus di Desa Adat Seminyak, Kecamatan Kuta, Kabupaten Badung). SOCA (SOCIOECONOMIC OF AGRICULTURRE AND AGRIBUSINESS), 7(1).

View in (Google Scholar)

13. Pitana, I. G., \& Diarta, I. K. S. (2009). Pengantar ilmu pariwisata. Yogyakarta: Andi. View in (Google Scholar)

Amerta, I. (2017). Community Based Tourism Development. International Journal Of Social Sciences And Humanities (IJSSH), 1(3), 97-107. doi:10.21744/ijssh.v1i3.60 
14. Pitana, I. G., \& Gayatri, P. G. (2005). Sosiologi pariwisata. Yogyakarta: Andi.

View in (Google Scholar)

15. Sunaryo, B. (2013). Kebijakan pembangunan destinasi pariwisata: konsep dan aplikasinya di Indonesia (No. 1). Penerbit Gava Media Kebijakan Pembangunan Destinasi Pariwisata: Konsep dan Aplikasinya di Indonesia.

View in (Google Scholar)

16. Amerta, I. M. S. (2017). The Role of Tourism Stakeholders at Jasri Tourism Village Development, Karangasem Regency. International Journal of Social Sciences and Humanities (IJSSH), 1(2), 20 28.

View in (Google Scholar)

17. Astawa, I. N., Mantra, I. B. N., \& Widiastuti, I. A. M. S. (2017). Developing Communicative English Language Tests for Tourism Vocational High School Students. International Journal of Social Sciences and Humanities (IJSSH), 1(2), 58-64.

View in (Google Scholar)

18. Maba, W., \& Mantra, I. B. N. (2017). An Analysis of Assessment Models Employed by The Indonesian Elementary School Teachers. International Journal of Social Sciences and Humanities (IJSSH), 1(1), 39-45.

View in (Google Scholar)

19.Perdue, R. R., Long, P. T., \& Allen, L. (1990). Resident support for tourism development. Annals of Tourism Research, 17(4), 586-599.

View in (Google Scholar) (Scopus)

20.Crompton, J. L., \& McKay, S. L. (1997). Motives of visitors attending festival events. Annals of tourism research, 24(2), 425-439.

View in (Google Scholar) (Scopus)

21.Buhalis, D. (1998). Strategic use of information technologies in the tourism industry. Tourism Management, 19(5), 409-421.

View in (Google Scholar) (Scopus)

22.Suryasa, I. W. (2015). Borrowing Technique in The Translation of Bali Live Magazine Into Indonesian. LINGUISTIKA, 21(41).

View in (Google Scholar)

23. Brohman, J. (1996). New directions in tourism for third world development. Annals of tourism research, 23(1), 48-70.

View in (Google Scholar) (Scopus)

24.Amerta, I. M. S., \& Mudana, I. G. The Meanings Of The Development Of Alternative Tourism At Jasri Village, Subagan Sub-District, Karangasem.

View in (Google Scholar) 


\section{Biography of Author}

I Made Suniastha Amerta, is a senior lecturer at the Management Study
Program, Faculty of Economics, Warmadewa University, Denpasar. E-mail
address: jrokadek@yahoo.co.id and phone number 081805533605; The last
education is the Doctorate of Cultural Studies Program, Udayana University
Denpasar. He has completed his bachelor academic at English Department
Study Program, Faculty of Letters Warmadewa University in 1998 and Master
of Tourism in Tourism Studies Program, Udayana university in 2005. He is
now interested in doing the research on the cultural tourism and management
field.

Amerta, I. (2017). Community Based Tourism Development. International Journal Of Social Sciences And Humanities (IJSSH), 1(3), 97-107. doi:10.21744/ijssh.v1i3.60 